\title{
Dead-end Stop Terminated Tree Support Cable Systems
}

\author{
E. Thomas Smiley
}

\begin{abstract}
Supplemental support systems are used to reduce the risk of failure of codominant stems. The goal of this study was to evaluate dead-end stop terminated cables used in trees and to compare the strength of small tree cable systems. Field evaluations comparing eyebolt and Wire Stop ${ }^{\circledR}$ anchored cables found an enlargement of the hole through the branch in 39\% of the Wire Stop terminations with a mean size of $6 \mathrm{~mm}$. Static break tests found that the strength of cable system varied with the strength of the wood and system configuration. From a system strength perspective in oak: bent eye screw lags < welded eye screw lag $=$ single swage stop $=$ single swage stop with washer $<$ double swage stop with washer $=$ eyebolt. In pine, bent eye screw lags $=$ welded eye screw lag = single swage stop $<$ single swage stop with washer $<$ double swage stop with washer = double swage stop with fender washer $<$ eyebolt.

Key Words. Codominant Stems; Eyebolts; Ferrule; Guys; Junction Failures; Lags; Support Cable; Swage Stops; Tree Failures; Tree Support System; V-crotch; and Wedge.
\end{abstract}

A codominant stem is a forked branch with nearly equal diameters, arising from a common junction and lacking a normal branch union (ISA 2009). Codominant stem junctions tend to be one of the weakest portions of a tree's structure (Gilman 2003; Smiley 2003; Kane 2007; Kane et al. 2008; Kane and Clouston 2008). Supplemental support systems are installed to limit the movement of codominant stems so that the junction is not stressed to the point of breakage (Thompson 1935; Thompson 1936; Mayne 1975; Smiley et al. 2000; James et al. 2002; ANSI 2006; Smiley and Lilly 2007). The supplemental support typically used in North America for this purpose is a cable system that consists of a length of seven strand galvanized Extra High Strength (EHS) steel cable terminated with a thimble and manufactured cable grip. The termination is anchored to the tree using eyebolts (including nuts and washers), lag threaded hooks (J-lags), or lag threaded eyes (Mayne 1975; Smiley and Lilly 2007). Cables, grips, thimbles, lags or bolts all come in different sizes to accommodate different tree and cable sizes. Therefore, to install a cable the arborist must have from six (two lags, two thimbles, two grips) to ten (two eyebolts, two nuts, two washers, two thimbles, two grips) pieces of hardware to terminate and anchor each cable for each branch size class.

In a nonscientific survey, arborists knowledgeable in tree support systems from major commercial arboriculture companies, universities, and arboricultural consulting firms were asked for their observations on cable system failures (author's unpublished data 2010). Specifically, if they had seen failure of eyebolts installed in support systems and if they had seen problems associated with the overgrowth of cable terminations. One of the 17 arborists reported having seen the failure of an eyebolt. That arborist explained that the bolts broke due to faulty installation and side loading. Three of the 17 arborists surveyed reported having seen failures associated with overgrown cables. All of these failures were related to cable corrosion. The arbor- ists reported that the more common cable failures they have seen were at the apex of the manufactured grip and when a lag hook/ eye opened or lag was pulled out of a branch. Grip failures were attributed to a lack of a thimble at the time of installation or the thimble falling out of the termination after it was installed.

In recent years, a number of dead-end stop termination systems have come to the arboricultural market, such as Wire Stop ${ }^{\circledR}$ (Steve Tillitski, Rigguy Inc., Athens, GA, U.S.), Endz (George Mellick, Shelter Tree, Wrentham, MA, U.S.), and Wedge-Grip ${ }^{\mathrm{TM}}$ Dead End (Preformed line products, Mayfield Village, OH, U.S.). These terminations are installed by inserting a cable in a hole through the branch and anchoring the cable with one of these devices on the side opposite of the working section of the cable. Stop-terminated systems claim the benefits of using a smaller diameter hole for the cable, since the hole only needs to be the diameter of the cable; simplified installation of the system since they have fewer parts; stocking of fewer parts since stops are selected for cable diameter, not branch diameter; and providing equal or greater strength than alternative products. Manufacturer pull tests of the Wire Stop indicate that the cable will fail before the Wire Stop (Steve Tillitski, pers. comm.). Dead-end stop terminations consist of one or two major parts for each end of the cable. These systems eliminate two of the arborist identified weak points of the traditional cable system, the grip and lags.

There is no mention of the cable size required for small trees or shrubs less than five centimeters in diameter in the ANSI A300 Standard (ANSI 2006). However, there are many large shrubs and small trees planted in the landscape that have codominant stems and therefore would benefit from support systems. An inexpensive and aesthetically unobtrusive cable system would be desirable for these plants.

While there may be benefits to dead-end stop terminated systems, there are several questions that need to be answered, including: how does the strength of the termina- 
tion compare to other fasteners, and what is the impact on the tree of having a flexible cable running through the branch?

This study had two components: a field evaluation of dead-end stop terminated cables in large trees and a strength evaluation of small diameter cable systems using static pull testing. The overall goal of the project was to evaluate dead-end stop terminated cables for use in landscape trees.

\section{MATERIALS AND METHODS}

\section{Field Study}

In July 2005, 20 supplemental support cables were installed in six species of trees on a hillside garden at the Bartlett Tree Research Laboratories in Charlotte, NC, U.S. Trees in the trial had two or three codominant stems with junctions within $1 \mathrm{~m}$ of the ground. One or two cables were installed in each tree. Cable used was a seven strand EHS cable, $0.48 \mathrm{~cm}(3 / 16$ inch) diameter with a listed breaking strength of $17.8 \mathrm{kN}$. EHS cable of this diameter is recommended for branches up to $20 \mathrm{~cm}$ in diameter (Smiley and Lilly 2007). The cable was either terminated with a manufactured grip (Preformed Line Products, Mayfield Village, $\mathrm{OH}$, U.S.) and a heavy duty thimble that was anchored to the tree using a $1.2 \mathrm{~cm}(1 / 2 \mathrm{inch})$ diameter eyebolt, or the cable was inserted through the tree and fastened with a Wire Stop 301 dead-end, wedge and ferrule, stop type fastener (RigGuy Inc., Athens, GA, U.S.). Ten trees with codominant stems in the same area were retained as control trees without cables. Tree species and treatments were willow oak (Quercus phellos) 1 eyebolt, 1 no cable; red oak (Q. rubra) 2 Wire Stop, 3 eyebolt, 4 no cable; white oak (Q. alba) 4 Wire Stop, 4 eyebolt, 3 no cable; blackgum (Nyssa sylvatica) 1 Wire Stop, 1 eyebolt, 3 no cable; hickory (Carya spp.) 1 eyebolt; and red maple (Acer rubrum) 2 Wire Stop, 1 no cable: Tree heights ranged from 19 to $26.5 \mathrm{~m}$. Mean branch diameter at the point of cable attachment was $16.1 \mathrm{~cm}(\mathrm{SD}=1.06)$.

Trees, cable, and cable terminations were visually inspected and measured on March 5, 2010. Factors evaluated included cable or branch failure, presence of visually apparent rust or other damage to the cable, degree of cable or anchor overgrowth by the tree, and evaluation of the hole that was drilled for the eyebolt or cable insertion. If there was an enlargement of the drilled hole, the hole was measured across the largest axis, from edge to edge. Initial hole diameter was subtracted from the measurement to provide a hole enlargement size. That number was averaged for all of the holes that were enlarged.

\section{Static Breaking Tests}

The static breaking strength of seven different cable attachments were compared when fastened to branch sections of two tree species. Detached, 2.5 to $9.0 \mathrm{~cm}$ diameter branch or trunk sections were harvested one to three days prior to testing and were in "green condition" at the time of the test. Test species were willow oak (Quercus phellos) and Virginia pine (Pinus virginiana). Oak samples were from five different trees and pine samples were from 15 trees, data was blended for analysis. Branch diameter was measured in-line with the hole drilled for the anchor or cable.

Cable attachments tested were (Figure 2):

1) Screw eye: A $5.8 \mathrm{~mm}$ (nominal $1 / 4$ inch) diameter bent eye lag (number $4,5.5 \mathrm{~cm}, 23 / 16$ inch long), installed in a $0.48 \mathrm{~cm}$

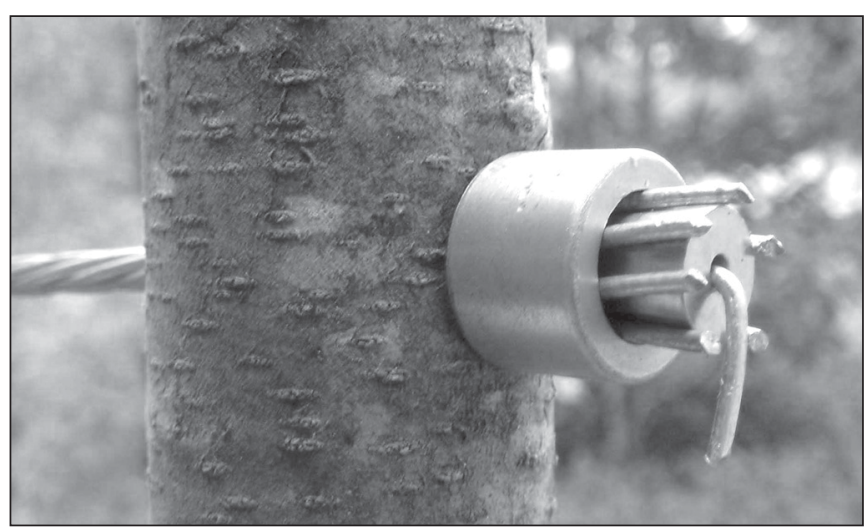

Figure 1. Wire Stop 301 dead-end, wedge and ferrule, stop type fastener (RigGuy Inc, Athens, GA, U.S.) installed in a small branch.

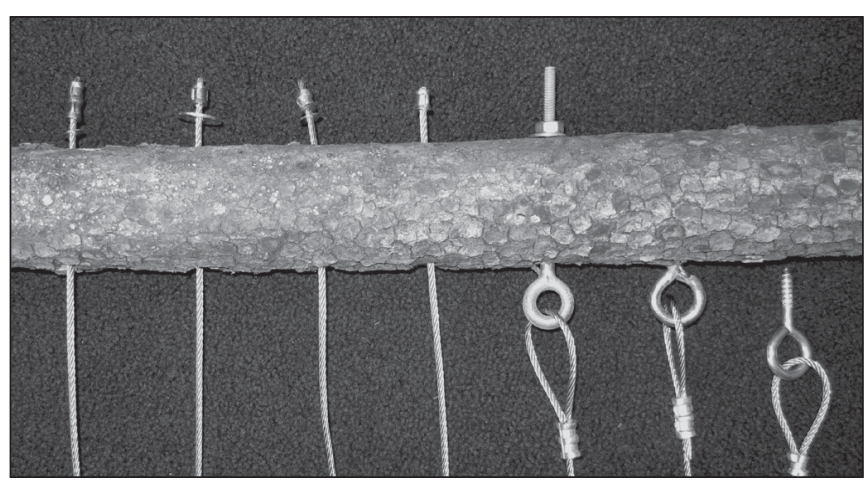

Figure 2. Cable systems that were evaluated using a static pull test. From left to right: double swage stop with washer, single swage stop with fender washer, single swage stop with washer, single swage stop without washer, eyebolt, welded eye lag, eye lag (not inserted in branch).

diameter hole that was drilled to a depth of approximately $19 \mathrm{~mm}$. The full depth of the threaded portion of the lag was screwed into the branch. The cable was attached through the eye with a $5 \mathrm{~cm}$ loop of cable secured with an oval swage connector.

2) Welded screw eye: A $5.8 \mathrm{~mm}$ (nominal $1 / 4$ inch) diameter bent eye lag (number $4,3.5 \mathrm{~cm}, 23 / 16$ inch long) that had the eye welded closed, installed in a $0.48 \mathrm{~cm}$ diameter hole that was drilled to a depth of approximately $1.9 \mathrm{~cm}$. The full depth of the threaded portion of the lag was screwed into the branch.

3) Eyebolt: A $5.8 \mathrm{~mm}$ (nominal $1 / 4$ inch) diameter drop forged galvanized steel eyebolt was installed through a $6.3 \mathrm{~mm}$ diameter hole that was drilled entirely through the branch. An $18.7 \mathrm{~mm}$ O.D., $7.7 \mathrm{~mm}$ I.D., $1.6 \mathrm{~mm}$ thick washer and nut was used to secure the bolt.

4) Single swage stop, no washer: A copper or aluminum swage stop was fastened to the dead end of a stainless or galvanized steel cable after it was inserted through a $0.40 \mathrm{~cm}$ diameter hole. A swaging tool (HIT 350-3, Japan) was used to crimp the swage stop.

5) Single swage stop with washer (Figure 3): A copper or aluminum swage stop was fastened to the dead end of a stainless or galvanized steel cable after it was inserted through a $0.40 \mathrm{~cm}$ diameter hole and a $1.12 \mathrm{~cm}$ O.D., $0.45 \mathrm{~cm}$ I.D., $0.9 \mathrm{~mm}$ thick (number 8) round, flat, stainless steel washer. The swage stop was securely crimped. 
6)Double swage stop, with washer:Aluminum swage stops were fastened to the dead end of the galvanized steel cable after it was inserted through a $0.40 \mathrm{~cm}(5 / 32 \mathrm{in})$ diameter hole; a $1.12 \mathrm{~cm}$ O.D., $0.45 \mathrm{~cm}$ I.D., $0.9 \mathrm{~mm}$ thick (number 8 ) round, flat, stainless steel washer. The two swage stops were installed adjacent to each other.

7) Double swage stop with fender washer: Copper or aluminum swage stop were fastened to the dead end of the cable after it was inserted through a $0.40 \mathrm{~cm}(5 / 32 \mathrm{in})$ diameter hole; a $22.5 \mathrm{~mm}$ (7/8 in) O.D., $4.7 \mathrm{~mm}$ (3/16 in) I.D., $1.4 \mathrm{~mm}$ thick round, flat, steel "fender washer." The two swage stops were installed adjacent to each other.

A galvanized or stainless steel $7 \times 7$ strand, $3.1 \mathrm{~mm}$ (1/8 in) diameter cable with a manufacturer rated breaking strength of $7.56 \mathrm{kN}$ [working load limit $(\mathrm{WLL})=1.5 \mathrm{kN}$ ] was used for all attachments. This size cable is recommended for branches between $2.5 \mathrm{~cm}$ and $12.5 \mathrm{~cm}$ in diameter (Smiley and Lilly 2007).

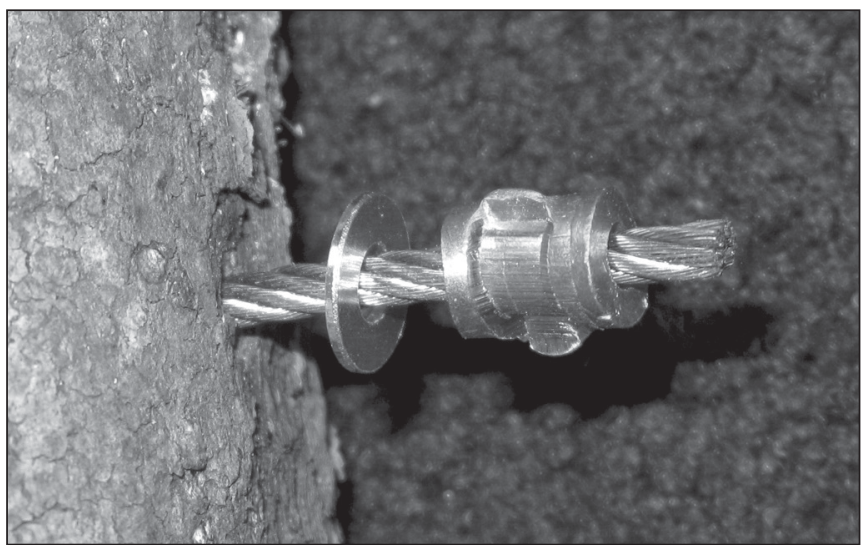

Figure 3. Close up of a crimped single swage stop terminated cable with washer.

Branches were positioned longitudinally across two steel pins that were $14 \mathrm{~cm}$ apart, with the cable attachment point near the center (Figure 4). Approximately $40 \mathrm{~cm}$ from the branch attachment, the cable was formed into a $5 \mathrm{~cm}$ eye fastened with an oval swage connector. The cable eye was connected with a steel carabiner to a peak reading dynamometer (Dillon ED 2000 plus, Kansas City, MO, U.S.), which was connected with a larger cable to a mechanical winch (Fulton, Mosinee, WI, U.S.). The winch was hand cranked until one part of the system failed. However, for reasons of operator safety, the winch was not intentionally operated in excess of $8.9 \mathrm{kN}$. Four to 25 tests were conducted per termination type per species. Fewer eye lags were tested for each species due to the consistency of failure pattern that was irrespective of species.

Peak force reading, branch diameter, and failure type were recorded for each test. However, tests were terminated for safety reasons when the peak load was near $8.9 \mathrm{kN}$; 'No failure' was recorded.

The data analysis was conducted separately for each species. The overall effect of the seven treatments (seven cable system categories) on the response (peak force at point of breakage) for each species was determined with an analysis of variance (ANOVA). If the ANOVA indicated an overall effect of the treatment on the response, specific comparisons of the mean responses among the eight treatments were determined using Tukey's Honestly Significant Difference Test (HSD). All analyses were conducted in SPSS (Chicago, IL, U.S.) and all statistical tests were performed using an alpha level of 0.05 .

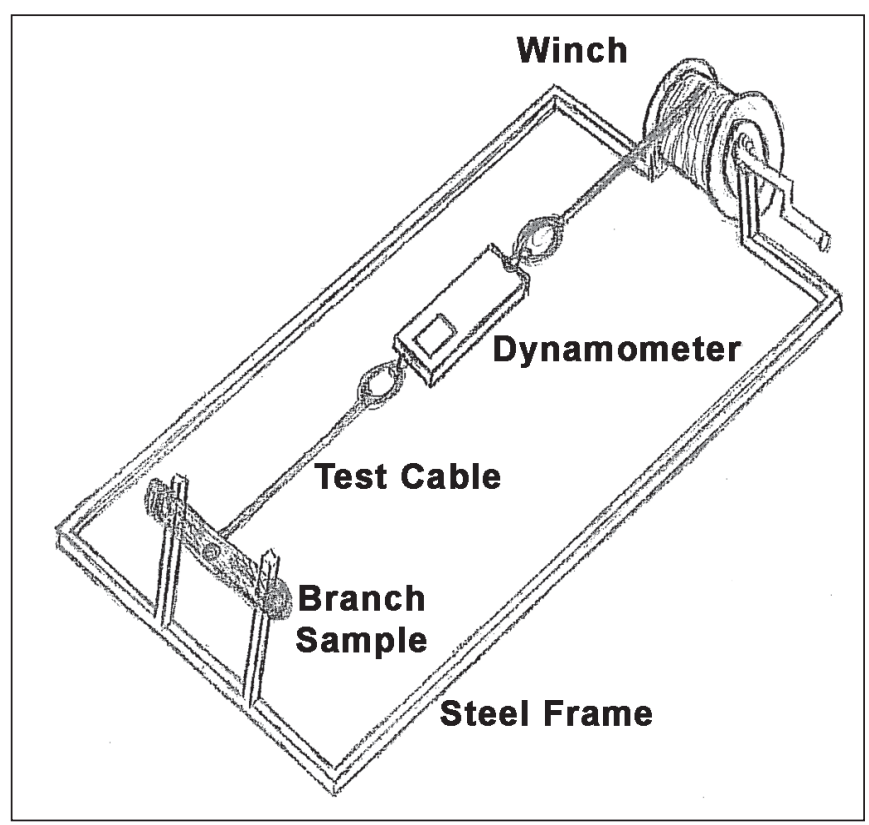

Figure 4. Representation of the devise used to test cable attachments to small branches. Not to scale.

\section{RESULTS}

\section{Field Study}

After a nearly five-year period, visual inspection of the cables, trees, and terminations found no failures of any termination, cable, cabled trees, or noncabled trees. Most trees had partially or fully overgrown the washer, nut, eyebolt or the Wire Stop fastener. None of the trees had enveloped the thimble and grip portion of the traditional cable system. None of the cables had visually apparent rust.

There were no visually apparent changes in the size of the hole associated with the eyebolt anchored cables. With Wire Stop terminations, the tree either grew into contact with the cable (11 of 18 terminations), or the cable enlarged the hole in the tree (7 of 18 terminations) (Figure 5; Figure 6). Hole enlargement occurred on five white oak and two red oak stems. When the hole was enlarged, the average degree of enlargement was $6 \mathrm{~mm}$.

\section{Static Breaking Tests}

In static breaking tests of cable systems installed in small diameter branches, it was found that eyebolt anchored cables were the strongest with a mean peak force of $8.5 \mathrm{kN}$ (Table 1; Figure 7; Figure 8). With oak, most tests were terminated when the force level approached $8.9 \mathrm{kN}$. However, four of the 13 tests broke the branch in which the eyebolt was installed. This resulted in a lower peak force $(8.3 \mathrm{kN})$ than if the broken branch force measurements were removed from the analysis. Without the broken branches, the mean peak force was 8.8 $\mathrm{kN}$, which is comparable to the value $(8.9 \mathrm{kN})$ found in pine.

At the other end of the strength spectrum was the bent eye lag screw which failed with the lowest mean force, approximately $2.1 \mathrm{kN}$. With screw hooks, the hook was straightened by the pulling force, allowing release of the cable. Tree species made no difference since there was no pull-out or branch breakage. 


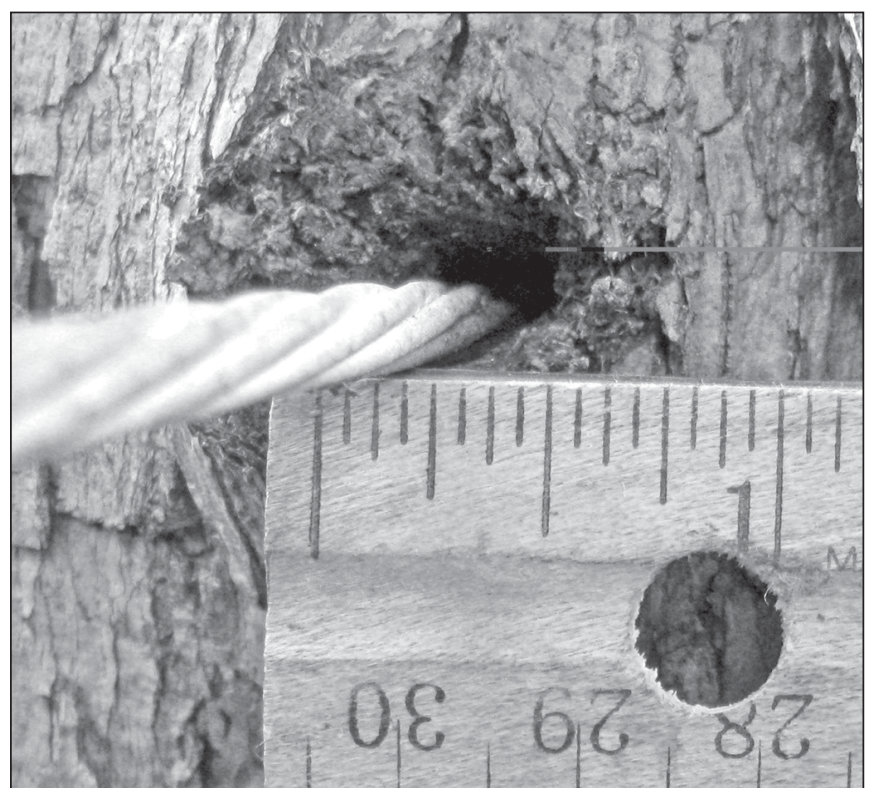

Figure 5. Galvanized EHS steel cable that has widened the hole in the bark and terminated with a Wire Stop fastener.

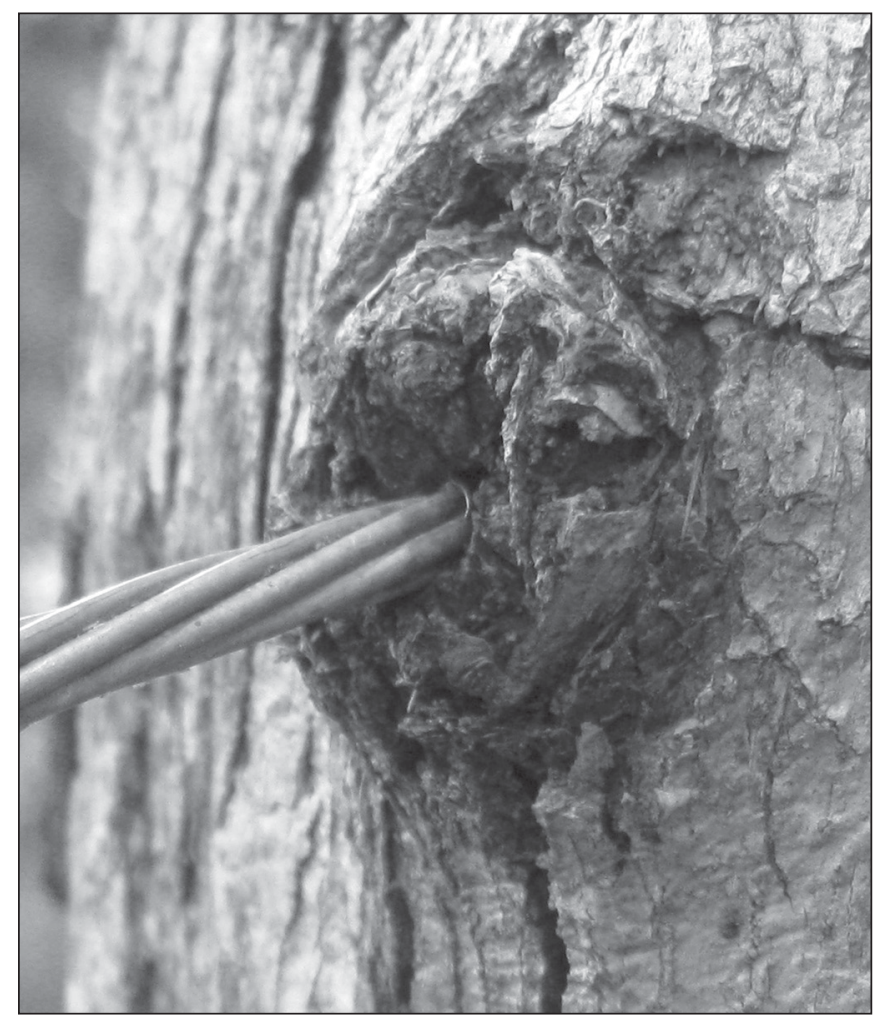

Figure 6. Galvanized EHS steel cable that has grown tightly against the cable with Wire Stop terminations.

Tests with exactly the same eye lags, except for the eye portion being welded closed, showed a significant increase in system strength in oak but not in pine. With both oak and pine, the failure mode changed from the opening of the lag eye, with the standard lag eye to pulling out of the wood, with the welded eye. Since oak wood is more resistant to fastener removal, welding the eye closed significantly increased the strength of the system from a mean of $2.1 \mathrm{kN}$ with the standard screw eye to $4.5 \mathrm{kN}$ with the welded eye.

With dead-end swage stop terminated cables, a single swage stop with no washer pulled through the wood of all of the pines with a mean force of $2.7 \mathrm{kN}$. This force level was not significantly different from either screw eye. In oaks, the majority of failures occurred when the swage stop failed at slightly less than $4 \mathrm{kN}$. With oak, this was a significantly higher peak force than the screw eye anchored cable systems, but not the welded screw eye system.

When a washer was added to the single swage stop terminated cable, the swage stop consistently pulled off the cable in oak with a mean peak force of $4.8 \mathrm{kN}$. In pine, the majority of failures were also when the swage stop failed. However, failures involving the swage stop pulling through and the branch breaking also occurred. With pine, the mean peak force increased $47 \%$ to near $4 \mathrm{kN}$, with the addition of a washer. The differences with and without washers were not significant.

When two swage stops and a washer were installed on the cable, the failures occurred near the listed breaking strength of the cable $(7.6 \mathrm{kN})$ with oaks. This level of force was not significantly different from the peak force associated with eyebolt terminations. The majority of these failures occurred when the cable broke (19 of 25 tests). For the remaining six samples, the entire anchor system pulled through the branch. Branch pull-through occurred on branches from 38 to $48 \mathrm{~mm}$ in caliper, and the cable broke on branches from 45 to $64 \mathrm{~mm}$ in caliper. With pine, the failures occurred at a lower mean force $(5.5 \mathrm{kN})$, with about half of the terminations pulling through the wood and the other half when the cable broke. The pullthroughs in pine were in the branch caliper range of 31 to 56 $\mathrm{mm}$ and cable breakage was in the caliper range of 76 to $86 \mathrm{~mm}$.

With pine, the washered double swage stop pulled through the branch slightly more often than the cable failed. So with pine, the larger diameter 'fender washer' was tested in place of the standard washer. There was no increase in system strength with the larger washer. However, the failure pattern changed from the swage stop pulling through the branch with the standard washer to the branch breaking with the fender washer. If the 'branch broke' samples were removed from the analysis, the mean strength increased from 5.4 to $7.0 \mathrm{kN}$, which indicates that the fender washer adds considerable strength as compared to a standard washer. Since cable failure was typical with willow oak with the washered double swage stops, fender washers were not needed or tested.

There was no oak branch breakage if the caliper of the branch was over $33 \mathrm{~mm}$, or in pine if the branch was over $52 \mathrm{~mm}$ in caliper, even when forces up to $8.9 \mathrm{kN}$ were applied to the cable.

\section{DISCUSSION}

The supplemental support cable system commonly used in North America consists of EHS cable, manufactured deadend grip, thimble, and eyebolt, seldom fail when installed and maintained in accordance with the ANSI A300 Standards (2006). Where failures were observed, they were typically with J-lags opening, screw eyes pulling out of the tree, or failure at the apex of the manufactured grip cable termination due to lack of a thimble (author's unpublished data 2010).

Failures associated with cables that had been overgrown from radial branch growth are apparently more related to cable corrosion rather than other reasons. This indirectly indi- 
Table 1. Small diameter cable system breakage test results.

\begin{tabular}{|c|c|c|c|c|}
\hline \multirow[t]{2}{*}{$\begin{array}{l}\text { Termination/Anchor } \\
\text { System Tested }\end{array}$} & \multicolumn{2}{|c|}{$\begin{array}{l}\text { Mean peak force at failure } \\
\text { in Newtons (number of samples) }\end{array}$} & \multicolumn{2}{|l|}{ Failure type } \\
\hline & Oak & Pine & Oak & Pine \\
\hline $\begin{array}{l}\text { Screw eye } \\
\text { Welded screw eye } \\
\text { Eyebolt }\end{array}$ & $\begin{array}{l}2098 \mathrm{a}^{*}(4) \\
4464 \mathrm{~b}(8) \\
8274 \mathrm{c}(13) \\
\text { Mean when } \\
\text { 'Branch broke' } \\
\text { samples removed } \\
8785(8)\end{array}$ & $\begin{array}{l}2070 \text { a (6) } \\
2453 \text { a (7) } \\
8903 \text { d (7) }\end{array}$ & $\begin{array}{l}\text { Eye opened } \\
\text { Pulled out of wood } \\
\text { No failure } 6 / 13 \\
\text { (test terminated } \\
\text { due to safety } \\
\text { considerations) } \\
\text { Eyebolt broke } 1 / 13 \\
\text { Cable broke } 2 / 13 \\
\text { Branch broke } 4 / 13\end{array}$ & $\begin{array}{l}\text { Eye opened } \\
\text { Pulled out of wood } \\
\text { No failure } 4 / 7 \\
\text { (test terminated } \\
\text { due to safety } \\
\text { considerations) } \\
\text { Pulled through } \\
\text { wood } 3 / 7\end{array}$ \\
\hline $\begin{array}{l}\text { Single swage stop } \\
\text { no washer }\end{array}$ & 3966 b (16) & $2757 \mathrm{ab}(12)$ & $\begin{array}{l}\text { Stop failed to hold } \\
\text { cable } 15 / 16 \\
\text { Stop pulled through } \\
\text { wood } 1 / 16\end{array}$ & $\begin{array}{l}\text { Stop pulled through } \\
\text { wood }\end{array}$ \\
\hline $\begin{array}{l}\text { Single swage stop } \\
\text { with washer }\end{array}$ & 4812 b (9) & 4079 b (11) & $\begin{array}{l}\text { Stop failed to hold } \\
\text { cable }\end{array}$ & $\begin{array}{l}\text { Stop failed to } \\
\text { hold cable } 8 / 11 \\
\text { Stop pulled through } \\
\text { wood } 2 / 11 \\
\text { Branch broke } 1 / 11\end{array}$ \\
\hline $\begin{array}{l}\text { Double swage stop } \\
\text { with washer }\end{array}$ & 7527 c (25) & 5530 c (9) & $\begin{array}{l}\text { Cable broke } 19 / 25 \\
\text { Stop pulled through } \\
\text { wood } 6 / 25\end{array}$ & $\begin{array}{l}\text { Cable broke } 4 / 9 \\
\text { Stop pulled through } \\
\text { wood } 5 / 9\end{array}$ \\
\hline $\begin{array}{l}\text { Double swage stop } \\
\text { with fender washer }\end{array}$ & Not tested & $\begin{array}{l}5420 \text { c }(13) \\
\text { Mean when } \\
\text { 'Branch broke' } \\
\text { samples removed } \\
7000(6)\end{array}$ & N/A & $\begin{array}{l}\text { Stop failure } 1 / 13 \\
\text { Cable broke } 5 / 13 \\
\text { Branch broke } 7 / 13\end{array}$ \\
\hline
\end{tabular}

* Force values followed by the same letter are not significantly different when compared using the Tukey HSD separation of means $(\alpha=0.05)$.

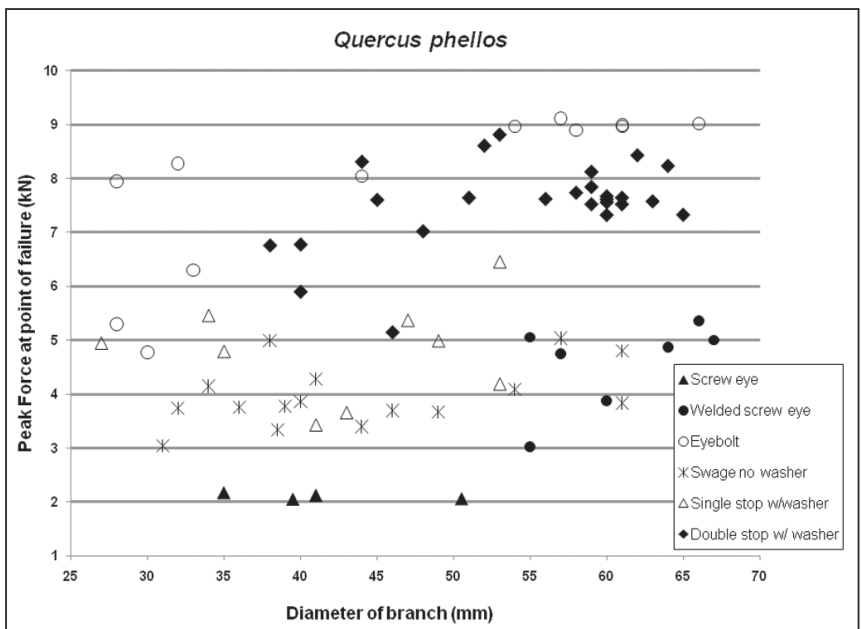

Figure 7. Peak force achieved when various cable attachments are pulled to failure in Quercus phellos branches ranging from 2.5 to $7 \mathrm{~cm}$ in diameter.

cates that there should not be frequent failures of dead-end stop terminated cables failing due to overgrowth by the tree.

Dead-end stop terminated cables provide benefits for arborists and trees including fewer parts to stock and the elimination of the weakest points of the traditional EHS system pointed out in an a nonscientific survey of arborists-lag anchors and manufactured grips. Wire Stop terminated cables inspected five years after installation were found to have no affect on cable corrosion, cable or branch breakage when compared to eyebolt anchored systems. The major difference between the eyebolt anchored system and the

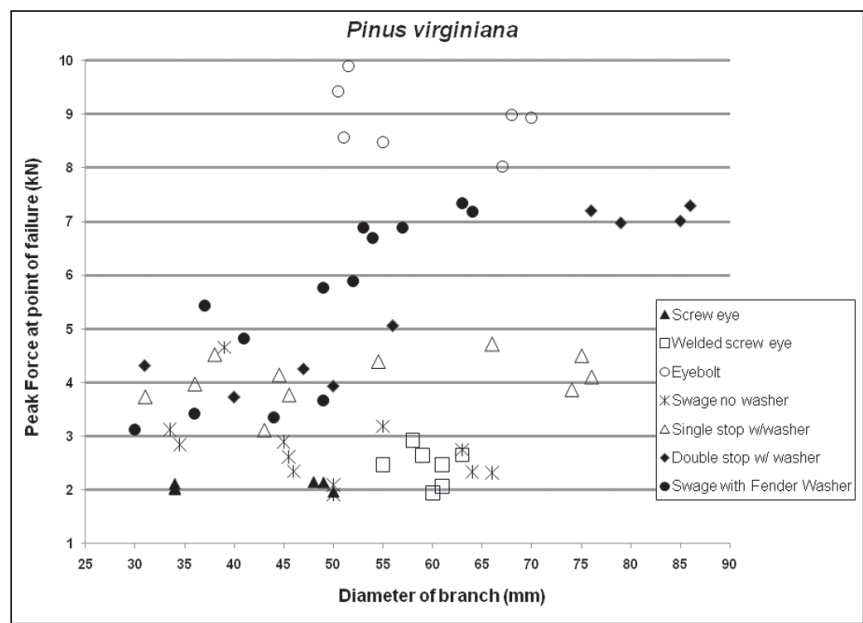

Figure 8. Peak force achieved when various cable attachments are pulled to failure in Pinus virginiana branches ranging from 2.5 to $7 \mathrm{~cm}$ in diameter.

Wire Stop terminated system was that the Wire Stop fastened system was associated with an enlargement in the hole drilled when installing the cable. Thirty-nine percent of the Wire Stop terminated cables enlarged the hole in the bark and wood around the cable.

The long term implications of hole enlargement are uncertain. In earlier studies of cables and wood decay (Shigo and Felix 1980; Kane and Ryan 2002), it was concluded that if anchors are not installed through existing areas of decay, they will have little impact on decay development in wood surrounding the anchors. However, if they are in- 
stalled by drilling into areas of decay, then the injury may predispose the wood to further decay development. Further research is needed to identify the factors associated with hole enlargement and means of preventing its development.

Tests conducted on various, traditionally terminated and swage stop terminated small diameter cable systems found that the strength of the system varied with the strength of the wood and the system configuration. From a system strength perspective in oak: bent eye screw lags $<$ welded eye screw lag $=$ single swage stop $=$ single swage stop with washer $<$ double swage stop with washer $=$ eyebolt. In pine, bent eye screw lags = welded eye screw lag = single swage stop $<$ single swage stop with washer $<$ double swage stop with washer $=$ double swage stop with fender washer $<$ eyebolt.

The strength of the eyebolt anchored cables actually exceeded the listed breaking strength of the cable. This may be due to the doubling of the cable in forming the loop which connected it to the eyebolt. Cable failures seen with other systems tested, and as reported by Thompson (1936), had a tendency to be near the surface of the branch, the area where a double cable was present with the eyebolt anchor.

Bent eye lags failed at about $25 \%$ of the force of eyebolts. This is somewhat less than Thompson (1936) reported for half-inch lag hooks, which failed at 33\% of comparably sized eyebolts. Strength of a washered swage stop terminated cable was nearly twice that of the bent eye lag anchored system that is commonly used in small trees.

An eyebolt terminated system provides nearly double the strength of the washered single swage stop system in soft wooded pine. Results showed that adding washers on single swage stops did not significantly increase the strength of the system. However, the nearly 50\% increase in strength with pine branches from the addition of a washer is well worth the additional cost of adding washers to the system when installing a swage stop cable in a small trees. Washers are most important in branches of smaller diameter where 'pull-through' type failure were more commonly observed than in larger diameter branches. On soft wooded species, increasing the diameter of a washer will also increase the strength of the system.

Cables in branches up to $12.7 \mathrm{~cm}$ (5 in) are intended to support a working load of $1.33 \mathrm{kN}$ (300 pounds) (Thompson 1935; Smiley and Lilly 2007), therefore the estimated $1.5 \mathrm{kN}$ (340 lbs) WLL of $0.31 \mathrm{~cm}$ (nominal 1/8-inch) diameter steel cable can be appropriate for branches up to $12.7 \mathrm{~cm}$ ( 5 in) at the point of cable attachment. The 4 to $4.8 \mathrm{kN}$ breaking strength (WWL approximated at 0.8 to $0.96 \mathrm{kN}, 180$ to 215 pound of force) of a washered single swage stop termination is appropriate for branches up to 7.6 to $8.9 \mathrm{~cm}$ ( 3 to 3.5 in) in diameter for soft and hard wooded species, respectively. For branches between 7.6 and $12.7 \mathrm{~cm}$ ( 3 and $5 \mathrm{in}$ ) in diameter the stronger washered double swage stop or eyebolt termination is necessary.

In a yearlong monitoring of cable tension in a single $29 \mathrm{~m}$ tall Eucalyptus cladocalyx in Australia, the peak cable tension recorded was only $4.3 \mathrm{kN}$ (James et al. 2002). This is less than the force required to break $3.1 \mathrm{~mm}$ (1/8 inch) cable with a washer and single swage stop. This tension data also indicates that the ANSI Standard (2006) and BMP (Smiley and Lilly 2007) may over estimate the forces applied to tree support cables. Additional research on dynamic cable tension would be valuable in determining the strength of systems required in trees.

Long-term, large tree trials are needed to fully understand the effects of dead-end stop terminated cables on the growth, health, and stability of trees in the landscape. With nearly $40 \%$ of the holes in this study being enlarged by the cable, the impact of this on the spread of decay becomes an important unanswered question. Dead-end stop terminated cables may be more appropriate on small trees where the risk of limb failure can be tolerated from a safety perspective. Lower side loading forces associated with smaller tree make the hole enlargement less likely. However, additional field testing of dead-end stop terminated small tree systems needs to be conducted to determine if there are weaknesses that were not apparent in the static test and to determine if hole enlargement is a factor that needs to be considered.

Acknowledgments. We would like to thank Robert Bartlett Jr. and the F.A. Bartlett Tree Expert Company for their support of this research, Bruce R. Fraedrich, Ph.D. Director of Research. Patrick Brewer, Bartlett District Manager for Texas for development of small swage stop cables; Liza Holmes Research Technician for small cable testing, data collection, graph development and paper editing; Elden LeBrun, Research Technician for installation of the large tree cables; Patrick Anderson for large tree cable assessment assisted by Jarod Faas, Skyler Schaeffer, Craig Robinson, production arborists at the Charlotte NC Bartlett office; Lorraine Graney for paper editing; Liz Brewer for Excel graphs; Billy Bridges from Clemson University for assistance with statistical analysis, George Palmer, Technician, for art work and data collection; and Steve Tillitski.

Arborists who contributed information to the cable failure survey were James Ackerman, David Anderson, Rex Bastian, Ph.D., Dane Buell, Jim Clark, Ph.D., Fred Fisher, Pat Flynn, Richard Herfurth, Brian Kane, Ph.D., Elden LeBrun, R.J. Leverne, Brian Maxson, Joe McNeil, Dennis Ryan, Ph.D. Rob Springer, Gareth Tudor-Jones, and Torrey Young. 


\section{LITERATURE CITED}

American National Standards Institute (ANSI). 2006. American National Standard for Tree Care Operations-Tree, Shrub, and Other Woody Plant Maintenance-Standard Practices (Support Systems a. Cabling, Bracing, and Guying (A300, Part 3). Tree Care Industry Association. Manchester, NH.

Gilman, E.F. 2003. Branch to stem diameter ratio affects strength of attachment. Journal of Arboriculture 29:291-294.

International Society of Arboriculture (ISA). 2009. Glossary of Arboriculture Terms. International Society of Arboriculture Press. Champaign IL. 141 pp.

James, K.R., N. Haritos, and P. Kenyon. 2002. Measuring loads on tree limbs and cables. In: E.T. Smiley and K. Coder (Eds.). Tree structure and mechanics conference proceeding: how trees stand up and fall down. ISA press. Champaign IL. pp. 125-138.

Kane, B. 2007. Branch strength of Bradford Pear. Arboriculture and Urban Forestry 33:283-291.

Kane, B., and P. Clouston. 2008. Tree pulling tests of large shade trees in the genus Acer. Arboriculture and Urban Forestry 34:101-109.

Kane, B., R. Ferrell, S.M. Zedaker, J.R. Loferski, and D.W. Smith. 2008. Failure mode and predication of the strength of branch attachments. Arboriculture \& Urban Forestry 34:308-316.

Kane, B.C.P., and H.D.P. Ryan. 2002. Discoloration and decay associated with hardware installation in trees. Journal of Arboriculture 28:187-193.

Mayne, L.S. Cabling and bracing. 1975. Journal of Arboriculture 1:101106.

Smiley, E.T. 2003. Does included bark reduce the strength of codominant stems? Journal of Arboriculture 29:104-106.

Smiley, E.T., C.M. Greco, and J.G. Williams. 2000. Brace rods for codominant stems: installation location and breaking strength. Journal of Arboriculture 26:170-176.

Smiley, E.T., and S. Lilly. 2007. Best Management Practices Tree support systems: Cabling, bracing and propping (Revised). ISA press. Champaign, IL. 35 pp.

Shigo, A.L,. and R. Felix. 1980. Cabling and bracing. Journal of Arboriculture 6:5-9.

Thompson, A.R. 1935. Tree bracing. Tree preservation bulletin No. 3 . U.S. National Park Service. 16 pp.

Thompson, A.R. 1936. Tree cabling materials. Proceedings of the National Shade Tree Conference. pp. 30-43.

\section{E. Thomas Smiley}

Bartlett Research Laboratories

13768 Hamilton $R d$.

Charlotte, NC 28278, U.S.
Résumé. Des systèmes de support sont employés pour diminuer le risque de bris de branches codominantes. Le but de cette étude était d'évaluer les systèmes d'ancrage des câbles utilisés dans les arbres ainsi que de comparer la force de petits systèmes d'ancrage. Les évaluations faites sur le terrain pour comparer le boulon à œil avec le système d'ancrage Wire Stop ${ }^{\circledR}$ ont permis d'observer de découvrir un élargissement du trou au travers de la branche d'en moyenne $6 \mathrm{~mm}$ dans $39 \%$ des cas avec le système Wire Stop. Des tests de rupture statique ont permis de découvrir que la force du câble varie avec la résistance du bois ainsi qu'avec la configuration de l'ensemble du système. En terme de perspective de force d'un système chez un chêne, on obtenait ce qui suit: crochet à œil < crochet à œil forgé = bague simple à sertir < bague simple à sertir avec rondelle $<$ double bague à sertir avec rondelle $=$ boulon à œil. Chez un pin: crochet à œil = crochet à œil forgé $=$ bague simple à sertir $<$ bague simple à sertir avec rondelle $<$ double bague à sertir avec rondelle $=$ double bague à sertir avec rondelle à diamètre variable < boulon à œil.

Zusammenfassung. Ergänzende Schutzeinrichtungen werden verwendet, um das Risiko des Versagens von kodominanten Stämmen zu reduzieren. Das Ziel dieser Studie war die Evaluierung von Kabeln mit einem stumpfen Ende, die bei Bäumen verwendet werden und vergleicht sie mit Kabelsystemen für kleine Bäume. Die feldseitigen Evaluierungen verglichen Kabel mit einer Augenschraube mit den durch Wire Stop ${ }^{\circledR}$ unterstützten Kabeln und fanden dabei heraus, dass sich in $39 \%$ der Fälle mit dem Wire Stop®-Kabel das Loch durchschnittlich um $6 \mathrm{~mm}$ vergrößert. Statistische Bruchtests fanden heraus, dass die Kraft der Kabelsysteme mit der Kraft des Holzes und der Systemkonfiguration variiert. Aus der Perspektive der Systemstärke bei Eichen gilt: Nachlauf der Schrauben mit gebogenem Auge < Nachlauf der Schraube mit geschweißtem Auge $=$ einfacher, geschmiedeter Stopp $=$ einfacher, geschmiedeter Stopp mit Scheibe $<$ doppelter, geschmiedeter Stopp mit Scheibe $=$ Augenbolzen . Bei Kiefern: Nachlauf der Schrauben mit gebogenem Auge = Nachlauf der Schraube mit geschweißtem Auge = einfacher, geschmiedeter Stopp $<$ einfacher, geschmiedeter Stopp mit Scheibe < doppelter, geschmiedeter Stopp mit Scheibe < doppelter, geschmiedeter Stopp mit gefederter Scheibe $<$ Augenbolzen.

Resumen. Sistemas de soporte suplementarios son empleados para reducir el riesgo de falla de ramas codominantes. El objetivo de este estudio fue evaluar los cables usados en árboles y comparar la resistencia de pequeños sistemas de cables. Las evaluaciones de campo comparando los cables con armella y anclados con el sistema Wire Stop ${ }^{\circledR}$ encontraron un alargamiento del hueco a través de la rama en 39\% de las terminales Wire Stop ${ }^{\circledR}$ con un tamaño medio de $6 \mathrm{~mm}$. Las pruebas de rotura estática encontraron que la resistencia del sistema del cable varió con la resistencia de la configuración de madera y sistema. Desde una perspectiva de sistema de resistencia en encino y pino: tornillos con ojo $<$ tuerca con arandela $=$ solamente el tornillo $=$ tornillo con ojo. 